\title{
High Temperature Solid Oxide Fuel Cell Generator Development
}

DOE Cooperative Agreement No. DE-FC26-97FT34139

Semi-Annual Technical Progress Report

Reporting Period:

February 21, 2006 - August 21, 2006

\section{Prepared for}

\author{
National Energy Technology Laboratory \\ U.S. Department of Energy \\ 3610 Collins Ferry Road \\ P. O. Box 880 \\ Morgantown, WV 26507-0880
}

by

Siemens Power Generation

Stationary Fuel Cells

George Westinghouse Science and Technology Center

1310 Beulah Road

Pittsburgh, PA 15235-5098

Program Manager: Joseph F. Pierre

September, 2006 


\section{DISCLAIMER}

This report was prepared as an account of work sponsored by an agency of the United States Government. Neither the United States Government nor any agency thereof, nor any of their employees, makes any warranty, express or implied, or assumes any legal liability or responsibility for the accuracy, completeness, or usefulness of any information, apparatus, product, or process disclosed, or represents that its use would not infringe privately owned rights. Reference herein to any specific commercial product, process or service by trade name, trademark, manufacturer, or otherwise does not necessarily constitute or imply its endorsement, recommendation, or favoring by the United States Government or any agency thereof. The views and opinions of authors expressed herein do not necessarily state or reflect those of the United States Government or any agency thereof. 


\begin{abstract}
Work performed during the period February 21, 2006 through August 21, 2006 is summarized herein. During this period, efforts were focused on $5 \mathrm{kWe}$ bundle testing, development of on-cell reformation, the conceptual design of an advanced module, and the development of a manufacturing roadmap for cells and bundles. A $5 \mathrm{kWe}$ SOFC system was built and delivered to the Pennsylvania State University; fabrication of a second 5 kWe SOFC for delivery to Montana State University was initiated. Cell testing and microstructural analysis in support of these efforts was also conducted.
\end{abstract}




\section{Executive Summary}

This report documents the work performed during the reporting period February 1, 2006 through August 21, 2006. During this period of performance, efforts focused on completing a $5 \mathrm{kWe}$ SOFC bundle test, development of on-cell reformation, the conceptual design of an advanced module, and the development of a manufacturing roadmap for cells and bundles. A $5 \mathrm{kWe}$ SOFC system was delivered to the Pennsylvania State University; fabrication of a 5 kWe SOFC for delivery to Montana State University was initiated.

The Alpha-7 bundle test was terminated after successfully operating for more than 1,200 hours. Advanced features incorporated into Alpha-7 included cells manufactured with a scandia-stabilized zirconia (ScSZ) electrolyte and composite interlayer, an improved internal recuperator design, enhanced stack thermal management features, a steam ethanol purge system, and lower cost recuperators and air feed tubes. Alpha-7 produced a maximum power of $5.44 \mathrm{kWe}(\mathrm{DC})$, approximately $1 \mathrm{kWe}$ greater than the peak power achieved with yttria-stabilized zirconia cells. The power increase was attributed to a combination of the ScSZ cells and the improved stack temperature distribution. The lower cost air feed tubes had no deleterious effects on cell performance. Shutdown of Alpha-7 using the steam-ethanol purge system was successfully demonstrated.

The preliminary analytical results from the anode reformation task indicated that the candidate anode reforming concepts would all experience some reduction in cell voltage. This voltage loss may be mitigated if the fuel flow to closed end of the cell is altered. Efforts also focused on reducing the reforming activity of not only the cell anode, but also all nickel components. Preliminary screening tests produced promising results with a significant reduction in reforming activity accompanied by a slight reduction in electrical performance.

Evaluation of advanced, lower cost bundle fabrication processes and a pre-sinter bundle repair technique continued. The gas composition required for bundle sintering processes was optimized. A technique for the disassembly, repair, and reassembly of bundles to replace damaged components was successfully demonstrated and qualified for use in manufacturing.

Extensive CFD and stress analysis efforts were dedicated to gaining a better understanding of the flow distribution and thermal stresses of the Air Ingress/Exhaust Manifold for the low temperature module. Significant progress was made in the rapid prototyping of thermally matched materials and small scale prototypes of the manifold were fabricated.

A number of concepts for the advanced module design were developed, aimed at achieving dramatic reductions in both material and fabrication costs. Significant progress was made in conceptualizing key components and developing innovative module configurations for the high power density SOFC. Efforts continued into determining the most suitable cell geometry for maximum stack power density and high fuel utilization.

The development of a manufacturing roadmap for cells and bundles was initiated. The objective is to apply the lessons learned in cell and bundle product and process 
development to the fabrication process proposed for high volume production. Programs which define the activities necessary to establish product and process development and validation of cell and bundles have been identified and established.

Fabrication of a 5 kWe SOFC for delivery, installation, and operation at Montana State University (MSU) was initiated. This system will incorporate the state-of-the-art cell, bundle, and module technology. Cell manufacturing, bundle fabrication were successfully completed. Module assembly is underway. The balance-of-plant is being prepared for module integration.

Details of the work completed during this report period are documented in the Appendix. 